\title{
Triggering of Suicidal Erythrocyte Death by Psammaplin A
}

\author{
Abdulla Al Mamun Bhuyan ${ }^{\mathrm{a}}$ Elena Signoretto ${ }^{\mathrm{a}, \mathrm{b}} \quad$ Florian Lang ${ }^{\mathrm{a}}$ \\ ${ }^{a}$ Departments of Cardiology, Vascular Medicine and Physiology, Eberhard-Karls-University of \\ Tuebingen, Tuebingen, Germany; ${ }^{\text {b}}$ Department of Pharmacological and Biomolecular Sciences, \\ Università degli Studi di Milano, Milano, Italy
}

\section{Key Words}

Phosphatidylserine $\bullet$ Cell volume $\bullet$ Eryptosis $•$ Oxidative stress $\bullet$ Ceramide $\bullet$ Calcium

\begin{abstract}
Background/Aims: Psammaplin A, a natural product isolated from marine sponges, triggers apoptosis of tumor cells and is thus considered for the treatment of malignancy. In analogy to apoptosis of nucleated tumor cells, erythrocytes may enter eryptosis, a suicidal death characterized by cell shrinkage and cell membrane scrambling with phosphatidylserine translocation to the erythrocyte surface. Cellular mechanisms stimulating eryptosis include increase of cytosolic $\mathrm{Ca}^{2+}$ activity $\left(\left[\mathrm{Ca}^{2+}\right]_{i}\right)$, oxidative stress and ceramide. The present study explored, whether Psammaplin A induces eryptosis and to possibly shed some light on the underlying mechanisms. Methods: Phosphatidylserine exposing erythrocytes were identified utilizing annexin-V-binding, cell volume was estimated from forward scatter, $\left[\mathrm{Ca}^{2+}\right]_{i}$ determined utilizing Fluo3-fluorescence, the abundance of reactive oxygen species (ROS) quantified with DCFDA dependent fluorescence, and ceramide abundance at the erythrocyte surface detected with specific antibodies. Results: A 48 hours exposure of human erythrocytes to Psammaplin A (2-8 $\mu \mathrm{g} / \mathrm{ml})$ significantly decreased forward scatter and significantly increased the percentage of annexin-V-binding cells. Psammaplin A significantly increased Fluo3fluorescence, the effect of Psammaplin A on annexin-V-binding and forward scatter was, however, not significantly blunted by removal of extracellular $\mathrm{Ca}^{2+}$. Psammaplin A significantly increased DCFDA fluorescence and ceramide abundance. Conclusions: Psammaplin A triggers cell shrinkage and phospholipid scrambling of the erythrocyte cell membrane, an effect paralleled by increase of $\left[\mathrm{Ca}^{2+}\right]_{i}$ induction of oxidative stress and enhanced appearance of ceramide.

\section{Introduction}

Psammaplin A, a symmetrical bromotyrosine-derived disulfide isolated from marine sponges [1-5], has previously been shown to trigger apoptosis of tumor cells [6-9] and is considered a potential drug for the treatment of malignancy [6-14]. Psammaplin A inhibits histone deacetylase and proved to be a powerful epigenetic modifier $[3,6,10,15-21]$. In 


\section{Cellular Physiology Cell Physiol Biochem 2016;39:908-918 \begin{tabular}{l|l|l} 
and BOI: 10.1159/000447800 & $\begin{array}{l}\text { (c) 2016 The Author(s). Published by S. Karger AG, Basel } \\
\text { www.karger.com/cpb }\end{array}$
\end{tabular}}

Al Mamun Bhuyan/Signoretto/Lang: Stimulation of Eryptosis by Psammaplin A

addition, the drug inhibits hepatitis C virus NS3 helicase and has thus been considered as antiviral drug [22]. Psammaplin A further inhibits chitinolytic enzymes and has antifungal and antibacterial potency [23-27].

Several substances triggering apoptosis of nucleated cells similarly trigger suicidal death of erythrocytes or eryptosis [28-70]. Eryptosis is characterized by cell shrinkage [71] and cell membrane scrambling with phosphatidylserine translocation to the cell surface [59]. Mechanisms involved in the stimulation of eryptosis include increase of cytosolic $\mathrm{Ca}^{2+}$ activity $\left(\left[\mathrm{Ca}^{2+}\right]_{\mathrm{i}}\right)[59]$, ceramide [72], oxidative stress [59], energy depletion [59], caspases $[59,73,74]$, and several kinases, such as casein kinase $1 \alpha$, Janus-activated kinase JAK3, protein kinase $\mathrm{C}$, and p38 kinase [59]. Other kinases, such as AMP activated kinase AMPK, cGMP-dependent protein kinase, PAK2 kinase and sorafenib/sunitinib sensitive kinases counteract eryptosis [59].

The present study explored, whether Psammaplin A may trigger eryptosis. To this end, human erythrocytes from healthy volunteers were exposed to Psammaplin A and phosphatidylserine translocation, cell volume, $\left[\mathrm{Ca}^{2+}\right]_{\mathrm{i}}$, oxidative stress, and ceramide abundance determined by flow cytometry.

\section{Materials and Methods}

\section{Erythrocytes, solutions and chemicals}

Fresh Li-Heparin-anticoagulated blood samples were kindly provided by the blood bank of the University of Tübingen. The study is approved by the ethics committee of the University of Tübingen (184/2003 V). The blood was centrifuged at $120 \mathrm{xg}$ for $20 \mathrm{~min}$ at $21^{\circ} \mathrm{C}$ and the platelets and leukocytes-containing supernatant was disposed. Erythrocytes were incubated in vitro at a hematocrit of $0.4 \%$ in Ringer solution containing (in mM) $125 \mathrm{NaCl}, 5 \mathrm{KCl}, 1 \mathrm{MgSO}_{4}, 32 \mathrm{~N}$-2-hydroxyethylpiperazine-N-2-ethanesulfonic acid (HEPES; pH 7.4), 5 glucose, $1 \mathrm{CaCl}_{2}$, at $37^{\circ} \mathrm{C}$ for 48 hours. Where indicated, erythrocytes were exposed for 48 hours to Psammaplin A (Santa Cruz Biotechnology, Texas, USA).

\section{Annexin-V-binding and forward scatter}

After incubation under the respective experimental condition, a $150 \mu \mathrm{l}$ cell suspension was washed in Ringer solution containing $5 \mathrm{mM} \mathrm{CaCl}_{2}$ and then stained with Annexin-V-FITC (1:200 dilution; ImmunoTools, Friesoythe, Germany) in this solution at $37^{\circ} \mathrm{C}$ for 15 min under protection from light. The annexin-Vabundance at the erythrocyte surface was subsequently determined on a FACS Calibur (BD, Heidelberg, Germany). Annexin-V-binding was measured with an excitation wavelength of $488 \mathrm{~nm}$ and an emission wavelength of $530 \mathrm{~nm}$. A marker (M1) was placed to set an arbitrary threshold between annexin-V-binding cells and control cells. The same threshold was used for untreated and Psammaplin A treated erythrocytes.

\section{Intracellular $\mathrm{Ca}^{2+}$}

After incubation, erythrocytes were washed in Ringer solution and then loaded with Fluo-3/AM (Biotium, Hayward, USA) in Ringer solution containing $5 \mathrm{mM} \mathrm{CaCl}_{2}$ and $5 \mu \mathrm{M}$ Fluo-3/AM. The cells were incubated at $37^{\circ} \mathrm{C}$ for $30 \mathrm{~min}$ and washed once in Ringer solution containing $5 \mathrm{mM} \mathrm{CaCl}$. The Fluo-3/ AM-loaded erythrocytes were resuspended in $200 \mu$ Ringer solution. Then, $\mathrm{Ca}^{2+}$-dependent fluorescence intensity was measured in FL-1 with an excitation wavelength of $488 \mathrm{~nm}$ and an emission wavelength of $530 \mathrm{~nm}$ on a FACS Calibur. Afterwards, the geomean of the $\mathrm{Ca}^{2+}$ dependent fluorescence was determined.

\section{Reactive oxygen species (ROS)}

Oxidative stress was determined utilizing 2',7'-dichlorodihydrofluorescein diacetate (DCFDA). After incubation, a $150 \mu \mathrm{l}$ suspension of erythrocytes was washed in Ringer solution and stained with DCFDA (Sigma, Schnelldorf, Germany) at a final concentration of $10 \mu \mathrm{M}$. Erythrocytes were incubated at $37^{\circ} \mathrm{C}$ for $30 \mathrm{~min}$ in the dark and washed two times in Ringer solution. The DCFDA-loaded erythrocytes were resuspended in $200 \mu$ l Ringer solution and ROS-dependent fluorescence intensity was measured in FL-1 at an excitation wavelength of $488 \mathrm{~nm}$ and an emission wavelength of $530 \mathrm{~nm}$ on a FACS Calibur (BD). Subsequently, the geomean of the DCFDA dependent fluorescence was determined. 


\section{Cellular Physiology Cell Physiol Biochem 2016;39:908-918

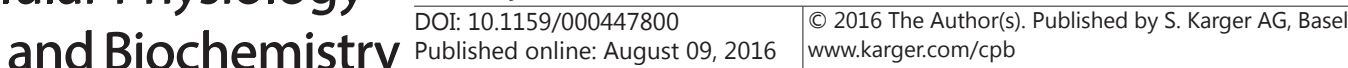 \\ Al Mamun Bhuyan/Signoretto/Lang: Stimulation of Eryptosis by Psammaplin A}

\section{Ceramide abundance}

To determine the ceramide abundance at the erythrocyte surface, a monoclonal antibody was used. After incubation, cells were stained for $1 \mathrm{~h}$ at $37^{\circ} \mathrm{C}$ with $1 \mu \mathrm{g} / \mathrm{ml}$ anti-ceramide antibody (clone MID 15B4; Alexis, Grünberg, Germany) in phosphate-buffered saline (PBS) containing $0.1 \%$ bovine serum albumin (BSA) at a dilution of 1:10. After two washing steps with PBS-BSA, cells were stained for 30 min with polyclonal fluorescein-isothiocyanate (FITC)-conjugated goat anti-mouse IgG/IgM (concentration $0.5 \mathrm{mg} /$ ml) specific antibody (BD Pharmingen, Hamburg, Germany) diluted 1:50 in PBS-BSA. Unbound secondary antibody was removed by repeated washing with PBS-BSA. Samples were then analyzed by flow cytometric analysis in FL-1 at an excitation wavelength of $488 \mathrm{~nm}$ and an emission wavelength of $530 \mathrm{~nm}$. Finally, the geomean of the ceramide dependent fluorescence was determined.

\section{Statistics}

Data are expressed as arithmetic means \pm SEM. As indicated in the figure legends, statistical analysis was made using ANOVA with Tukey's test as post-test and $t$ test as appropriate. $\mathrm{n}$ denotes the number of different erythrocyte specimens studied. Since different erythrocyte specimens used in distinct experiments are differently susceptible to triggers of eryptosis, the same erythrocyte specimens have been used for control and experimental conditions.

\section{Results}

The present study aimed to possibly disclose an effect of Psammaplin A on eryptosis, the suicidal erythrocyte death, which is characterized by cell shrinkage and phospholipid scrambling of the cell membrane with phosphatidylserine translocation to the cell surface.

Forward scatter in flow cytometry was taken as measure of erythrocyte volume. The measurements were performed after a 48 hours incubation of the erythrocytes in Ringer solution without or with Psammaplin A ( $2-8 \mu \mathrm{g} / \mathrm{ml})$. As shown in Fig. 1, Psammaplin A significantly decreased erythrocyte forward scatter at all Psammaplin A concentrations tested.

Phosphatidylserine exposing erythrocytes were identified utilizing annexin-V-binding, which was quantified by flow cytometry. The measurements were again made after a 48 hours incubation of the erythrocytes in Ringer solution without or with Psammaplin A (2

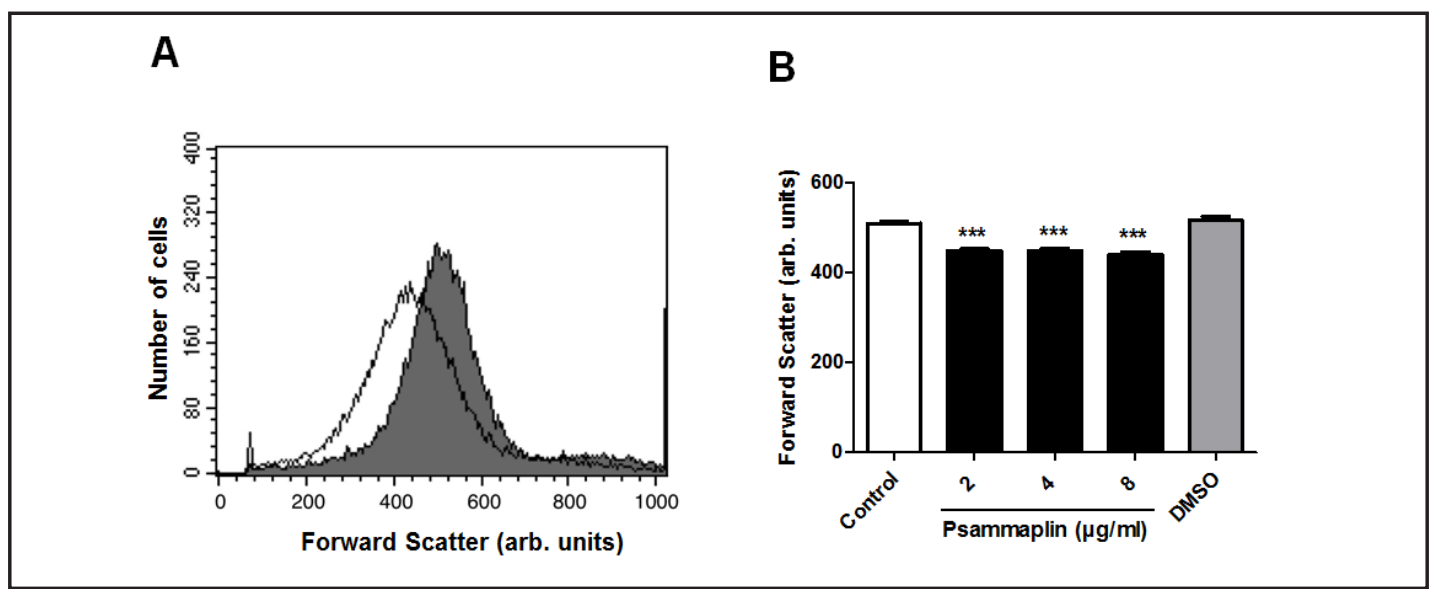

Fig. 1. Effect of Psammaplin A on erythrocyte forward scatter. A. Original histogram of forward scatter of erythrocytes following exposure for 48 hours to Ringer solution without (grey area) and with (black line) presence of $8 \mu \mathrm{g} / \mathrm{ml}$ Psammaplin A. B. Arithmetic means \pm SEM $(\mathrm{n}=8)$ of the erythrocyte forward scatter (FSC) following incubation for 48 hours to Ringer solution without (white bar) or with (black bars) Psammaplin A (2- $8 \mu \mathrm{g} / \mathrm{ml})$. For comparison, the effect of the solvent DMSO is shown (grey bar). ${ }^{* * *}(\mathrm{p}<0.001)$ indicates significant difference from the absence of Psammaplin A (ANOVA). 
A

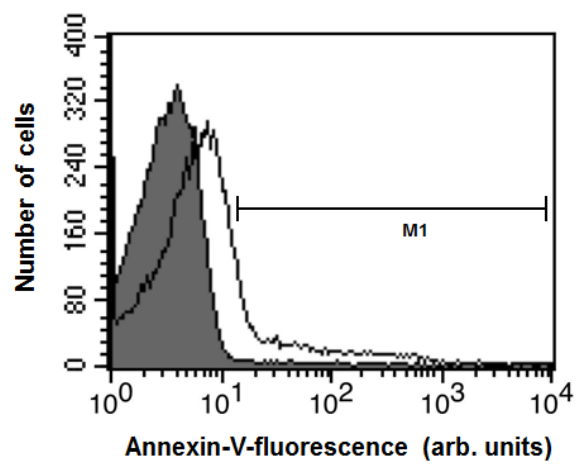

B

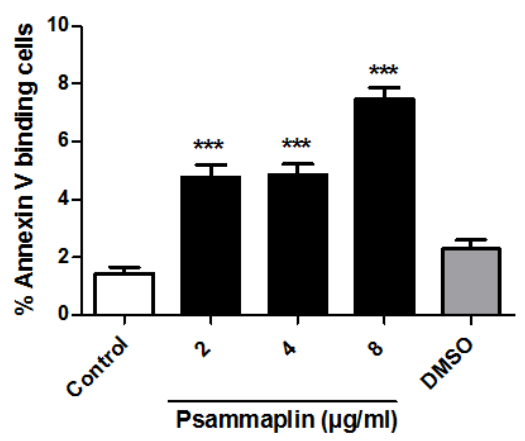

Fig. 2. Effect of Psammaplin A on phosphatidylserine exposure. A. Original histogram of annexin-V-binding of erythrocytes following exposure for 48 hours to Ringer solution without (grey area) and with (black line) presence of $8 \mu \mathrm{g} / \mathrm{ml}$ Psammaplin A. B. Arithmetic means \pm SEM $(n=8)$ of erythrocyte annexin-V-binding following incubation for 48 hours to Ringer solution without (white bar) or with (black bars) Psammaplin A $(2-8 \mu \mathrm{g} / \mathrm{ml})$. For comparison, the effect of the solvent DMSO is shown (grey bar). ${ }^{* * *}(\mathrm{p}<0.001)$ indicates significant difference from the absence of Psammaplin A (ANOVA).

\section{A}

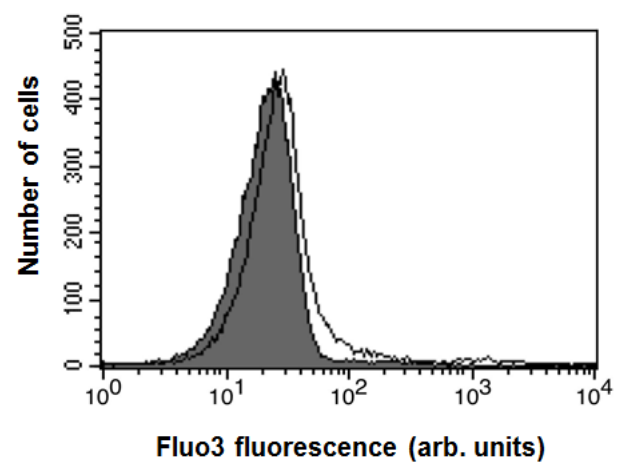

B

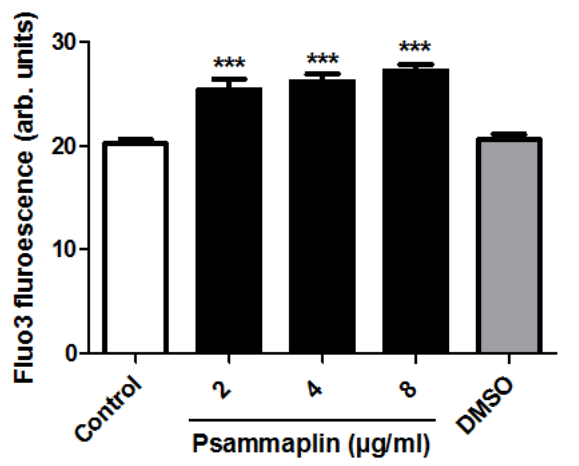

Fig. 3. Effect of Psammaplin A on Fluo3 fluorescenc. A. Original histogram of Fluo3 fluorescence of erythrocytes following exposure for 48 hours to Ringer solution without (grey area) and with (black line) presence of $8 \mu \mathrm{g} / \mathrm{ml}$ Psammaplin A. B. Arithmetic means \pm SEM $(\mathrm{n}=13)$ of erythrocyte Fluo3 fluorescence following incubation for 48 hours to Ringer solution without (white bar) or with (black bars) Psammaplin A (2 - $8 \mu \mathrm{g}$ / $\mathrm{ml})$. For comparison, the effect of the solvent DMSO is shown (grey bar). ${ }^{* * *}(\mathrm{p}<0.001)$ indicates significant difference from the absence of Psammaplin A (ANOVA).

- $8 \mu \mathrm{g} / \mathrm{ml}$ ). As illustrated in Fig. 2, a 48 hours exposure to Psammaplin A (2-8 $4 \mathrm{~g} / \mathrm{ml})$ significantly increased the percentage of phosphatidylserine exposing erythrocytes.

Cytosolic $\mathrm{Ca}^{2+}$ activity $\left(\left[\mathrm{Ca}^{2+}\right]_{\mathrm{i}}\right)$ was estimated utilizing Fluo3 fluorescence. The measurements were again made after a 48 hours incubation of the erythrocytes in Ringer solution without or with Psammaplin A $(2-8 \mu \mathrm{g} / \mathrm{ml})$. As apparent from Fig. 3, a 48 hours exposure to Psammaplin A $(2-8 \mu \mathrm{g} / \mathrm{ml})$ increased the Fluo3 fluorescence, an effect statistically significant at all Psammaplin A concentrations tested.

In order to test, whether the Psammaplin A-induced cell shrinkage and translocation of phosphatidylserine or erythrocyte shrinkage required entry of extracellular $\mathrm{Ca}^{2+}$, erythrocytes were incubated for 48 hours in the absence or presence of $8 \mu \mathrm{g} / \mathrm{ml}$ Psammaplin 
A
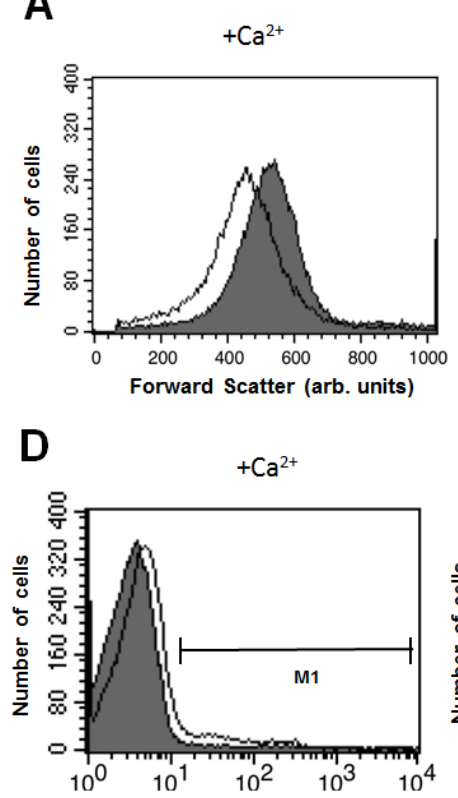

Annexin-V-fluorescence (arb. units)
B
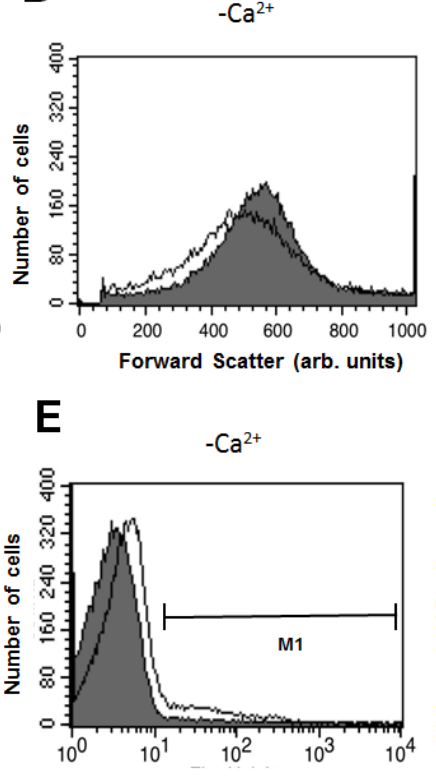

Annexin-V-fluorescence (arb. units)

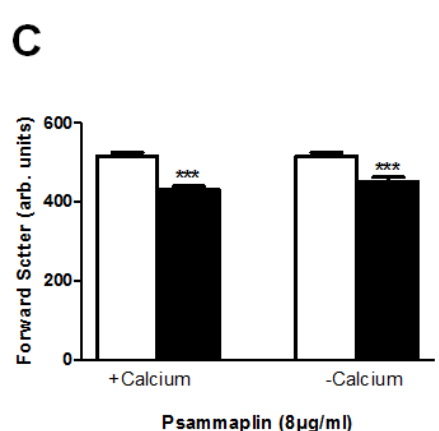

$\mathbf{F}$

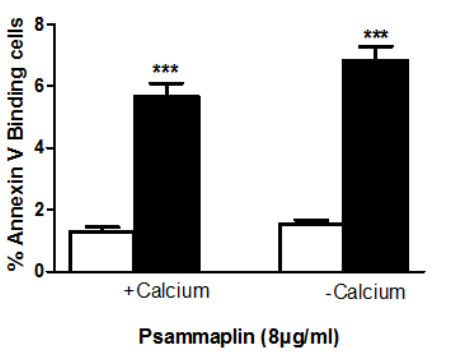

Fig. 4. $\mathrm{Ca}^{2+}$ insensitivity of Psammaplin A-induced erythrocyte shrinkage and phosphatidylserine exposure. A,B. Original histograms of erythrocyte forward scatter following exposure for 48 hours to Ringer solution without (grey area) and with (black line) Psammaplin A $(8 \mu \mathrm{g} / \mathrm{ml})$ in the presence (A) and absence (B) of extracellular $\mathrm{Ca}^{2+}$. C. Arithmetic means \pm SEM $(\mathrm{n}=13)$ of erythrocyte forward scatter after a 48 hours treatment with Ringer solution without (white bars) or with (black bars) Psammaplin A (8 $\mu \mathrm{g} / \mathrm{ml}$ ) in the presence (left bars, $+\mathrm{Ca}^{2+}$ ) and absence (right bars, $\left.-\mathrm{Ca}^{2+}\right)$ of $\mathrm{Ca}^{2+} . * * *(\mathrm{p}<0.001)$ indicates significant difference from the absence of Psammaplin A (ANOVA). D,E. Original histograms of annexin-V-exposing erythrocytes following exposure for 48 hours to Ringer solution without (grey area) and with (black line) Psammaplin A $(8 \mu \mathrm{g} / \mathrm{ml})$ in the presence (D) and absence (E) of extracellular $\mathrm{Ca}^{2+}$. F. Arithmetic means \pm SEM $(\mathrm{n}=13)$ of the percentage of annexin-V-exposing erythrocytes after a 48 hours treatment with Ringer solution without (white bars) or with (black bars) Psammaplin A $(8 \mu \mathrm{g} / \mathrm{ml})$ in the presence (left bars, $\left.+\mathrm{Ca}^{2+}\right)$ and absence (right bars, $\left.-\mathrm{Ca}^{2+}\right)$ of $\mathrm{Ca}^{2+} .{ }^{* * *}(\mathrm{p}<0.001)$ indicates significant difference from the absence of Psammaplin $\mathrm{A}$ (ANOVA).

A in the presence or nominal absence of extracellular $\mathrm{Ca}^{2+}$. As illustrated in Fig. 4A-C, removal of extracellular $\mathrm{Ca}^{2+}$ did not significantly blunt the effect of Psammaplin A on forward scatter. Even in the absence of extracellular $\mathrm{Ca}^{2+}$, Psammaplin A significantly decreased the erythrocyte forward scatter. Thus, Psammaplin A-induced cell shrinkage was in large part triggered by mechanisms other than entry of extracellular $\mathrm{Ca}^{2+}$.

Similar observations were made with annexin-V-binding. Removal of extracellular $\mathrm{Ca}^{2+}$ did not significantly blunt the effect of Psammaplin A on the percentage of annexin-V-binding erythrocytes and even in the absence of extracellular $\mathrm{Ca}^{2+}$, Psammaplin A significantly increased the percentage of annexin-V-binding erythrocytes (Fig. 4D-F). Thus, Psammaplin A-induced cell membrane scrambling was in large part triggered by mechanisms other than entry of extracellular $\mathrm{Ca}^{2+}$.

Eryptosis is further stimulated by oxidative stress. Reactive oxygen species (ROS) was thus quantified utilizing $2^{\prime}, 7^{\prime}$-dichlorodihydrofluorescein diacetate (DCFDA). As illustrated in Fig. 5A,B, the DCFDA fluorescence was significantly increased following a 48 hours exposure to $8 \mu \mathrm{g} / \mathrm{ml}$ Psammaplin. Thus, Psammaplin A induced oxidative stress.

A further stimulator of eryptosis is ceramide. Ceramide abundance at the erythrocyte surface was thus quantified utilizing specific antibodies. As a result, the ceramide abundance was significantly increased following a 48 hours exposure to $8 \mu \mathrm{g} / \mathrm{ml}$ Psammaplin (Fig. 5C,D). 


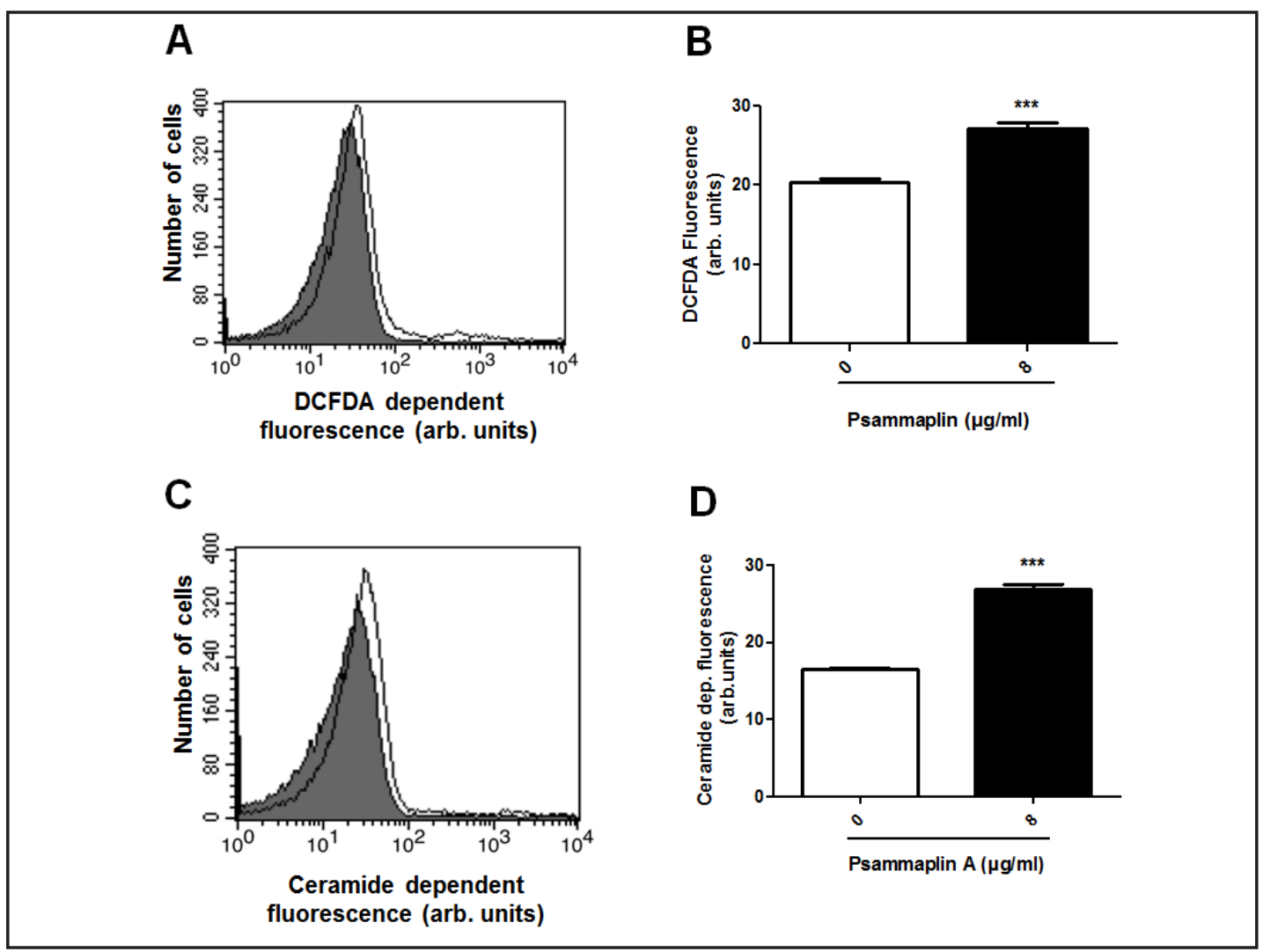

Fig. 5. Effect of Psammaplin A on DCFDA fluorescence and ceramide abundance. A. Original histogram of DCFDA fluorescence of erythrocytes following exposure for 48 hours to Ringer solution without (grey area) and with (black line) presence of $8 \mu \mathrm{g} / \mathrm{ml}$ Psammaplin A. B. Arithmetic means \pm SEM $(\mathrm{n}=9$ ) of DCFDA fluorescence of erythrocytes following incubation for 48 hours to Ringer solution without (white bar) or with (black bar) Psammaplin A $(8 \mu \mathrm{g} / \mathrm{ml}) .{ }^{* * *}(\mathrm{p}<0.001)$ indicates significant difference from the absence of Psammaplin A (unpaired $t$ test). C. Original histogram of ceramide abundance at the surface of erythrocytes following exposure for 48 hours to Ringer solution without (grey area) and with (black line) presence of $8 \mu \mathrm{g} / \mathrm{ml}$ Psammaplin A. D. Arithmetic means \pm SEM $(\mathrm{n}=5)$ of ceramide abundance at the surface of erythrocytes following incubation for 48 hours to Ringer solution without (white bar) or with (black bar) Psammaplin A $(8 \mu \mathrm{g} / \mathrm{ml}) .{ }^{* * *}(\mathrm{p}<0.001)$ indicates significant difference from the absence of Psammaplin A (unpaired $t$ test).

\section{Discussion}

The present study revealed a novel effect of Psammaplin A, i.e. the stimulation of eryptosis, the suicidal erythrocyte death. A 48 hours treatment of eythrocytes with Psammaplin A was followed by cell shrinkage and phospholipid scrambling of the cell membrane with phosphatidylserine translocation to the erythrocyte surface. The concentration required to trigger eryptosis was in the range of plasma concentrations (up to $5.2 \pm 0.8 \mu \mathrm{g} / \mathrm{ml}$ ) encountered in Psammaplin treated rats [75]. The sensitivity to Psammaplin A is presumably enhanced in several clinical conditions with accelerated eryptosis, such as dehydration [76], hyperphosphatemia [77], chronic kidney disease (CKD) [78-81], hemolytic-uremic syndrome [82], diabetes [83], hepatic failure [84], malignancy [59], sepsis [85], sickle-cell disease [59], beta-thalassemia [59], Hb-C and G6PD-deficiency [59], as well as Wilson's disease [86].

The effect of Psammaplin A on cell membrane scrambling was paralleled by an increase of cytosolic $\mathrm{Ca}^{2+}$ activity $\left(\left[\mathrm{Ca}^{2+}\right]_{\mathrm{j}}\right.$ ). However, the Psammaplin A induced cell membrane scrambling was not appreciably blunted by removal of extracellular calcium and thus not dependent on $\mathrm{Ca}^{2+}$ 


\section{Cellular Physiology Cell Physiol Biochem 2016;39:908-918 and Biochemistry Published online: August 09, $2016 \quad \begin{aligned} & \text { D } 2016 \text { The Author(s). Published by S. Karger AG, Basel } \\ & \text { www.karger.com/cpb }\end{aligned}$}

Al Mamun Bhuyan/Signoretto/Lang: Stimulation of Eryptosis by Psammaplin A

entry from the extracellular space. Accordingly, the effect of Psammaplin A on cell membrane scrambling was accomplished even in the absence of extracellular $\mathrm{Ca}^{2+}$.

The effect of Psammaplin A on cell shrinkage was again seemingly independent from $\mathrm{Ca}^{2+}$ entry from the extracellular space. Nevertheless, the Psammaplin A induced cell shrinkage could at least in part be due to increase of $\left[\mathrm{Ca}^{2+}\right]_{\mathrm{i}}$ with subsequent activation of $\mathrm{Ca}^{2+}$ sensitive $\mathrm{K}^{+}$channels, $\mathrm{K}^{+}$exit, cell membrane hyperpolarization, $\mathrm{Cl}^{-}$exit and thus cellular loss of $\mathrm{KCl}$ with water.

Mechanisms possibly contributing to Psammaplin A induced eryptosis further include oxidative stress and ceramide, both well known stimulators of eryptosis [59].

The physiological significance of eryptosis is the removal of defective erythrocytes from circulating blood thus avoiding hemolysis [59] with release of hemoglobin, which could pass the renal glomerular filter, precipitate in the acidic lumen of renal tubules, occlude the respective nephrons and thus cause renal failure [87]. Eryptosis may particularly lead to elimination of erythrocytes infected with the malaria pathogen Plasmodium [59]. It is tempting to speculate that Psammaplin A could accelerate the clearance of infected erythrocytes and thus favourably influence the clinical course of malaria.

Due to the rapid clearance of phosphatidylserine exposing erythrocytes from circulating blood, stimulation of eryptosis may lead, on the other hand, to anemia [59]. Excessive eryptosis may further compromize microcirculation [72, 88-92], as phosphatidylserine exposing erythrocytes adhere to the vascular wall [93], stimulate blood clotting and trigger thrombosis $[88,94,95]$.

In conclusion, Psammaplin A triggers eryptosis with cell shrinkage and cell membrane scrambling, an effect paralleled by increase of cytosolic $\mathrm{Ca}^{2+}$ activity, oxidative stress and ceramide abundance.

\section{Acknowledgements}

The authors acknowledge the meticulous preparation of the manuscript by Tanja Loch. The study was supported by the Deutsche Forschungsgemeinschaft and Open Access Publishing Fund of Tuebingen University.

\section{Disclosure Statement}

The authors state that they have no conflict of interest.

\section{References}

1 Godert AM, Angelino N, Woloszynska-Read A, Morey SR, James SR, Karpf AR, Sufrin JR: An improved synthesis of psammaplin A. Bioorg Med Chem Lett 2006;16:3330-3333.

2 Hentschel F, Sasse F, Lindel T: Fluorescent analogs of the marine natural product psammaplin A: synthesis and biological activity. Org Biomol Chem 2012;10:7120-7133.

3 Mallol A, Santalo J, Ibanez E: Psammaplin a improves development and quality of somatic cell nuclear transfer mouse embryos. Cell Reprogram 2014;16:392-406.

4 Pham NB, Butler MS, Quinn RJ: Isolation of psammaplin A 11'-sulfate and bisaprasin 11'-sulfate from the marine sponge Aplysinella rhax. J Nat Prod 2000;63:393-395.

5 Yang Q Liu D, Sun D, Yang S, Hu G, Wu Z, Zhao L: Synthesis of the marine bromotyrosine psammaplin F and crystal structure of a psammaplin A analogue. Molecules 2010;15:8784-8795.

6 Ahn MY, Jung JH, Na YJ, Kim HS: A natural histone deacetylase inhibitor, Psammaplin A, induces cell cycle arrest and apoptosis in human endometrial cancer cells. Gynecol Oncol 2008;108:27-33.

7 Hong S, Shin Y, Jung M, Ha MW, Park Y, Lee YJ, Shin J, Oh KB, Lee SK, Park HG: Efficient synthesis and biological activity of Psammaplin A and its analogues as antitumor agents. Eur J Med Chem 2015;96:218230. 


\section{Cellular Physiology Cell Physiol Biochem 2016;39:908-918 and Biochemistry \begin{tabular}{l|l} 
DOI: 10.1159/000447800 & (c) 2016 The Author(s). Published by S. Karger AG, Basel \\
www.karger.com/cpb
\end{tabular} \\ Al Mamun Bhuyan/Signoretto/Lang: Stimulation of Eryptosis by Psammaplin A}

8 Kim TH, Kim HS, Kang YJ, Yoon S, Lee J, Choi WS, Jung JH, Kim HS: Psammaplin A induces Sirtuin 1-dependent autophagic cell death in doxorubicin-resistant MCF-7/adr human breast cancer cells and xenografts. Biochim Biophys Acta 2015;1850:401-410.

9 Mora FD, Jones DK, Desai PV, Patny A, Avery MA, Feller DR, Smillie T, Zhou YD, Nagle DG: Bioassay for the identification of natural product-based activators of peroxisome proliferator-activated receptor-gamma (PPARgamma): the marine sponge metabolite psammaplin A activates PPARgamma and induces apoptosis in human breast tumor cells. J Nat Prod 2006;69:547-552.

10 Garcia J, Franci G, Pereira R, Benedetti R, Nebbioso A, Rodriguez-Barrios F, Gronemeyer H, Altucci L, de Lera AR: Epigenetic profiling of the antitumor natural product psammaplin A and its analogues. Bioorg Med Chem 2011;19:3637-3649.

11 Jiang Y, Ahn EY, Ryu SH, Kim DK, Park JS, Yoon HJ, You S, Lee BJ, Lee DS, Jung JH: Cytotoxicity of psammaplin A from a two-sponge association may correlate with the inhibition of DNA replication. BMC Cancer 2004; $4: 70$.

12 Kim D, Lee IS, Jung JH, Lee CO, Choi SU: Psammaplin A, a natural phenolic compound, has inhibitory effect on human topoisomerase II and is cytotoxic to cancer cells. Anticancer Res 1999;19:4085-4090.

13 Kim HJ, Kim TH, Seo WS, Yoo SD, Kim IH, Joo SH, Shin S, Park ES, Ma ES, Shin BS: Pharmacokinetics and tissue distribution of psammaplin A, a novel anticancer agent, in mice. Arch Pharm Res 2012;35:18491854.

14 Shim JS, Lee HS, Shin J, Kwon HJ: Psammaplin A, a marine natural product, inhibits aminopeptidase N and suppresses angiogenesis in vitro. Cancer Lett 2004;203:163-169.

15 Baud MG, Haus P, Leiser T, Meyer-Almes FJ, Fuchter MJ: Highly ligand efficient and selective N-2(Thioethyl)picolinamide histone deacetylase inhibitors inspired by the natural product psammaplin A. ChemMedChem 2013;8:149-156.

16 Baud MG, Leiser T, Haus P, Samlal S, Wong AC, Wood RJ, Petrucci V, Gunaratnam M, Hughes SM, Buluwela L, Turlais F, Neidle S, Meyer-Almes FJ, White AJ, Fuchter MJ: Defining the mechanism of action and enzymatic selectivity of psammaplin A against its epigenetic targets. J Med Chem 2012;55:1731-1750.

17 Baud MG, Leiser T, Meyer-Almes FJ, Fuchter MJ: New synthetic strategies towards psammaplin A, access to natural product analogues for biological evaluation. Org Biomol Chem 2011;9:659-662.

18 Baud MG, Leiser T, Petrucci V, Gunaratnam M, Neidle S, Meyer-Almes FJ, Fuchter MJ: Thioester derivatives of the natural product psammaplin A as potent histone deacetylase inhibitors. Beilstein J Org Chem 2013;9:81-88.

19 Kim DH, Shin J, Kwon HJ: Psammaplin A is a natural prodrug that inhibits class I histone deacetylase. Exp Mol Med 2007;39:47-55.

20 McCulloch MW, Coombs GS, Banerjee N, Bugni TS, Cannon KM, Harper MK, Veltri CA, Virshup DM, Ireland CM: Psammaplin A as a general activator of cell-based signaling assays via HDAC inhibition and studies on some bromotyrosine derivatives. Bioorg Med Chem 2009;17:2189-2198.

21 Pereira R, Benedetti R, Perez-Rodriguez S, Nebbioso A, Garcia-Rodriguez J, Carafa V, Stuhldreier M, Conte M, Rodriguez-Barrios F, Stunnenberg HG, Gronemeyer H, Altucci L, de Lera AR: Indole-derived psammaplin A analogues as epigenetic modulators with multiple inhibitory activities. J Med Chem 2012;55:9467-9491.

22 Salam KA, Furuta A, Noda N, Tsuneda S, Sekiguchi Y, Yamashita A, Moriishi K, Nakakoshi M, Tsubuki M, Tani H, Tanaka J, Akimitsu N: Psammaplin A inhibits hepatitis C virus NS3 helicase. J Nat Med 2013;67:765-772.

23 Hiusen TJ, Kamble-Shripat T: Delayed toxicity of two chitinolytic enzyme inhibitors (psammaplin a and pentoxifylline) against eastern subterranean termites (Isoptera: Rhinotermitidae). J Econ Entomol 2013;106:1788-1793.

24 Kim D, Lee IS, Jung JH, Yang SI: Psammaplin A, a natural bromotyrosine derivative from a sponge, possesses the antibacterial activity against methicillin-resistant Staphylococcus aureus and the DNA gyrase-inhibitory activity. Arch Pharm Res 1999;22:25-29.

25 Nicolaou KC, Hughes R, Pfefferkorn JA, Barluenga S: Optimization and mechanistic studies of psammaplin A type antibacterial agents active against methicillin-resistant Staphylococcus aureus (MRSA). Chemistry 2001;7:4296-4310.

26 Nicolaou KC, Hughes R, Pfefferkorn JA, Barluenga S, Roecker AJ: Combinatorial synthesis through disulfide exchange: discovery of potent psammaplin A type antibacterial agents active against methicillin-resistant Staphylococcus aureus (MRSA). Chemistry 2001;7:4280-4295. 


\section{Cellular Physiology Cell Physiol Biochem 2016;39:908-918 \begin{tabular}{l|l|l}
\hline DOI: 10.1159/000447800 & $\begin{array}{l}\text { C) 2016 The Author(s). Published by S. Karger AG, Basel } \\
\text { www.karger.com/cpb }\end{array}$
\end{tabular} \\ Al Mamun Bhuyan/Signoretto/Lang: Stimulation of Eryptosis by Psammaplin A}

27 Tabudravu JN, Eijsink VG, Gooday GW, Jaspars M, Komander D, Legg M, Synstad B, van Aalten DM: Psammaplin A, a chitinase inhibitor isolated from the Fijian marine sponge Aplysinella rhax. Bioorg Med Chem 2002;10:1123-1128.

28 Alzoubi K, Calabròa S, Bissinger R, Abed M, Faggio C, Lang F: Stimulation of Suicidal Erythrocyte Death by Artesunate. Cell Physiol Biochem 2014;34:2232-2244.

29 Alzoubi K, Egler J, Abed M, Lang F: Enhanced Eryptosis Following Auranofin Exposure. Cell Physiol Biochem 2015;37:1018-1028.

30 Arnold M, Bissinger R, Lang F: Mitoxantrone-induced suicidal erythrocyte death. Cell Physiol Biochem 2014;34:1756-1767.

31 Arnold M, Lang E, Modicano P, Bissinger R, Faggio C, Abed M, Lang F: Effect of nitazoxanide on erythrocytes. Basic Clin Pharmacol Toxicol 2014;114:421-426.

32 Bissinger R, Barking S, Alzoubi K, Liu G, Liu G, Lang F: Stimulation of Suicidal Erythrocyte Death by the Antimalarial Drug Mefloquine. Cell Physiol Biochem 2015;36:1395-1405.

33 Bissinger R, Bouguerra G, Stockinger K, Abbes S, Lang F: Triggering of Suicidal Erythrocyte Death by Topotecan. Cell Physiol Biochem 2015;37:1607-1618.

34 Bissinger R, Fischer S, Jilani K, Lang F: Stimulation of Erythrocyte Death by Phloretin. Cell Physiol Biochem 2014;34:2256-2265.

35 Bissinger R, Lupescu A, Zelenak C, Jilani K, Lang F: Stimulation of eryptosis by cryptotanshinone. Cell Physiol Biochem 2014;34:432-442.

36 Bouguerra G, Aljanadi O, Bissinger R, Abbes S, Lang F: Embelin-Induced Phosphatidylserine Translocation in the Erythrocyte Cell Membrane. Cell Physiol Biochem 2015;37:1629-1640.

37 Bouguerra G, Bissinger R, Abbes S, Lang F: Stimulation of Eryptosis by Narasin. Cell Physiol Biochem 2015;37:1807-1816.

38 Bouguerra G, Bissinger R, Abbes S, Lang F: Zopolrestat Induced Suicidal Death of Human Erythrocytes. Cell Physiol Biochem 2015;37:1537-1546.

39 Briglia M, Fazio A, Faggio C, Laufer S, Alzoubi K, Lang F: Triggering of Suicidal Erythrocyte Death by Ruxolitinib. Cell Physiol Biochem 2015;37:768-778.

40 Briglia M, Fazio A, Signoretto E, Faggio C, Lang F: Edelfosine Induced Suicidal Death of Human Erythrocytes. Cell Physiol Biochem 2015;37:2221-2230.

41 Calabro S, Alzoubi K, Faggio C, Laufer S, Lang F: Triggering of Suicidal Erythrocyte Death Following Boswellic Acid Exposure. Cell Physiol Biochem 2015;37:131-142.

42 Egler J, Lang F: Licochalcone A Induced Suicidal Death of Human Erythrocytes. Cell Physiol Biochem 2015;37:2060-2070.

43 Faggio C, Alzoubi K, Calabro S, Lang F: Stimulation of suicidal erythrocyte death by PRIMA-1. Cell Physiol Biochem 2015;35:529-540.

44 Fazio A, Briglia M, Faggio C, Alzoubi K, Lang F: Stimulation of Suicidal Erythrocyte Death by Garcinol. Cell Physiol Biochem 2015;37:805-815.

45 Jacobi J, Lang E, Bissinger R, Frauenfeld L, Modicano P, Faggio C, Abed M, Lang F: Stimulation of erythrocyte cell membrane scrambling by mitotane. Cell Physiol Biochem 2014;33:1516-1526.

46 Lang E, Jilani K, Bissinger R, Rexhepaj R, Zelenak C, Lupescu A, Lang F, Qadri SM: Vitamin D-Rich Diet in Mice Modulates Erythrocyte Survival. Kidney Blood Press Res 2015;40:403-412.

47 Lang E, Zelenak C, Eberhard M, Bissinger R, Rotte A, Ghashghaeinia M, Lupescu A, Lang F, Qadri SM: Impact of Cyclin-Dependent Kinase CDK4 Inhibition on Eryptosis. Cell Physiol Biochem 2015;37:1178-1186.

48 Lupescu A, Bissinger R, Goebel T, Salker MS, Alzoubi K, Liu G, Chirigiu L, Mack AF, Qadri SM, Lang F: Enhanced suicidal erythrocyte death contributing to anemia in the elderly. Cell Physiol Biochem 2015;36:773-783.

49 Lupescu A, Bissinger R, Herrmann T, Oswald G, Jilani K, Lang F: Induction of suicidal erythrocyte death by novobiocin. Cell Physiol Biochem 2014;33:670-680.

50 Lupescu A, Bissinger R, Warsi J, Jilani K, Lang F: Stimulation of erythrocyte cell membrane scrambling by gedunin. Cell Physiol Biochem 2014;33:1838-1848.

51 Malik A, Bissinger R, Calabro S, Faggio C, Jilani K, Lang F: Aristolochic Acid Induced Suicidal Erythrocyte Death. Kidney Blood Press Res 2014;39:408-419.

52 Officioso A, Alzoubi K, Manna C, Lang F: Clofazimine Induced Suicidal Death of Human Erythrocytes. Cell Physiol Biochem 2015;37:331-341. 


\section{Cellular Physiology Cell Physiol Biochem 2016;39:908-918 \begin{tabular}{l|l|l}
\hline DOI: 10.1159/000447800 & $\begin{array}{l}\text { C) 2016 The Author(s). Published by S. Karger AG, Basel } \\
\text { www.karger.com/cpb }\end{array}$ \\
\hline
\end{tabular} \\ Al Mamun Bhuyan/Signoretto/Lang: Stimulation of Eryptosis by Psammaplin A}

53 Oswald G, Alzoubi K, Abed M, Lang F: Stimulation of suicidal erythrocyte death by ribavirin. Basic Clin Pharmacol Toxicol 2014;114:311-317.

54 Peter T, Bissinger R, Enkel S, Alzoubi K, Oswald G, Lang F: Programmed erythrocyte death following in vitro Treosulfan treatment. Cell Physiol Biochem 2015;35:1372-1380.

55 Stockinger K, Bissinger R, Bouguerra G, Abbes S, Lang F: Enhanced Eryptosis Following Exposure to Carnosic Acid. Cell Physiol Biochem 2015;37:1779-1791.

56 Tesoriere L, Attanzio A, Allegra M, Cilla A, Gentile C, Livrea MA: Oxysterol mixture in hypercholesterolemiarelevant proportion causes oxidative stress-dependent eryptosis. Cell Physiol Biochem 2014;34:1075-1089.

57 Waibel S, Bissinger R, Bouguerra G, Abbes S, Lang F: Saquinavir Induced Suicidal Death of Human Erythrocytes. Cell Physiol Biochem 2015;37:1973-1982.

58 Zierle J, Bissinger R, Egler J, Lang F: Lapatinib Induced Suicidal Death of Human Erythrocytes. Cell Physiol Biochem 2015;37:2275-2287.

59 Lang E, Lang F: Mechanisms and pathophysiological significance of eryptosis, the suicidal erythrocyte death. Semin Cell Dev Biol 2015;39:35-42.

60 Bissinger R, Bouguerra G, Al Mamun Bhuyan A, Waibel S, Abbes S, Lang F: Efavirenz Induced Suicidal Death of Human Erythrocytes. Cell Physiol Biochem 2015;37:2496-2507.

61 Bissinger R, Waibel S, Bouguerra G, Al Mamun Bhuyan A, Abbes S, Lang F: Enhanced Eryptosis Following Exposure to Lopinavir. Cell Physiol Biochem 2015;37:2486-2495.

62 Briglia M, Calabro S, Signoretto E, Alzoubi K, Laufer S, Faggio C, Lang F: Fucoxanthin Induced Suicidal Death of Human Erythrocytes. Cell Physiol Biochem 2015;37:2464-2475.

63 Briglia M, Fazio A, Faggio C, Lang F: Triggering of Suicidal Erythrocyte Death by Zosuquidar. Cell Physiol Biochem 2015;37:2355-2365.

64 Fazio A, Briglia M, Faggio C, Alzoubi K, Lang F: Oxaliplatin Induced Suicidal Death of Human Erythrocytes. Cell Physiol Biochem 2015;37:2393-2404.

65 Macczak A, Cyrkler M, Bukowska B, Michalowicz J: Eryptosis-inducing activity of bisphenol A and its analogs in human red blood cells (in vitro study). J Hazard Mater 2016;307:328-335.

66 Officioso A, Alzoubi K, Lang F, Manna C: Hydroxytyrosol inhibits phosphatidylserine exposure and suicidal death induced by mercury in human erythrocytes: Possible involvement of the glutathione pathway. Food Chem Toxicol 2016;89:47-53.

67 Officioso A, Manna C, Alzoubi K, Lang F: Bromfenvinphos induced suicidal death of human erythrocytes. Pestic Biochem Physiol 2016;126:58-63.

68 Qadri SM, Donkor DA, Bhakta V, Eltringham-Smith LJ, Dwivedi DJ, Moore JC, Pepler L, Ivetic N, Nazi I, FoxRobichaud AE, Liaw PC, Sheffield WP: Phosphatidylserine externalization and procoagulant activation of erythrocytes induced by Pseudomonas aeruginosa virulence factor pyocyanin. J Cell Mol Med 2016;10.1111/jcmm.12778

69 Zierle J, Bissinger R, Bouguerra G, Abbes S, Lang F: Triggering of Suicidal Erythrocyte Death by Regorafenib. Cell Physiol Biochem 2016;38:160-172.

70 Pagano M, Faggio C: The use of erythrocyte fragility to assess xenobiotic cytotoxicity. Cell Biochem Funct 2015;33:351-355.

71 Lang PA, Kaiser S, Myssina S, Wieder T, Lang F, Huber SM: Role of Ca2+-activated K+ channels in human erythrocyte apoptosis. Am J Physiol Cell Physiol 2003;285:C1553-C1560.

72 Abed M, Towhid ST, Mia S, Pakladok T, Alesutan I, Borst O, Gawaz M, Gulbins E, Lang F: Sphingomyelinaseinduced adhesion of eryptotic erythrocytes to endothelial cells. Am J Physiol Cell Physiol 2012;303:C991999.

73 Lau IP, Chen H, Wang J, Ong HC, Leung KC, Ho HP, Kong SK: In vitro effect of CTAB- and PEG-coated gold nanorods on the induction of eryptosis/erythroptosis in human erythrocytes. Nanotoxicology 2012;6:847856.

74 Maellaro E, Leoncini S, Moretti D, Del Bello B, Tanganelli I, De Felice C, Ciccoli L: Erythrocyte caspase-3 activation and oxidative imbalance in erythrocytes and in plasma of type 2 diabetic patients. Acta Diabetol 2013;50:489-495.

75 Lee JY, Lee MY, Ha MW, Won TH, Cho HJ, Shin J, Park HG, Kim DD: Determination and validation of psammaplin $\mathrm{A}$ and its derivatives in rat plasma by liquid chromatography-tandem mass spectrometry and its application in pharmacokinetic study. J Chromatogr B Analyt Technol Biomed Life Sci 2015;1000:155-162. 


\section{Cellular Physiology Cell Physiol Biochem 2016;39:908-918 and Biochemistry \begin{tabular}{l|l} 
DOI: 10.1159/000447800 & (c) 2016 The Author(s). Published by S. Karger AG, Basel \\
www.karger.com/cpb
\end{tabular} \\ Al Mamun Bhuyan/Signoretto/Lang: Stimulation of Eryptosis by Psammaplin A}

76 Abed M, Feger M, Alzoubi K, Pakladok T, Frauenfeld L, Geiger C, Towhid ST, Lang F: Sensitization of erythrocytes to suicidal erythrocyte death following water deprivation. Kidney Blood Press Res 2013;37:567-578.

77 Voelkl J, Alzoubi K, Mamar AK, Ahmed MS, Abed M, Lang F: Stimulation of suicidal erythrocyte death by increased extracellular phosphate concentrations. Kidney Blood Press Res 2013;38:42-51.

78 Abed M, Artunc F, Alzoubi K, Honisch S, Baumann D, Foller M, Lang F: Suicidal erythrocyte death in endstage renal disease. J Mol Med (Berl) 2014;92:871-879.

79 Ahmed MS, Langer H, Abed M, Voelkl J, Lang F: The uremic toxin acrolein promotes suicidal erythrocyte death. Kidney Blood Press Res 2013;37:158-167.

80 Polak-Jonkisz D, Purzyc L: Ca(2+) influx versus efflux during eryptosis in uremic erythrocytes. Blood Purif 2012;34:209-210; author reply 210.

81 Calderon-Salinas JV, Munoz-Reyes EG, Guerrero-Romero JF, Rodriguez-Moran M, Bracho-Riquelme RL, Carrera-Gracia MA, Quintanar-Escorza MA: Eryptosis and oxidative damage in type 2 diabetic mellitus patients with chronic kidney disease. Mol Cell Biochem 2011;357:171-179.

82 Lang PA, Beringer O, Nicolay JP, Amon O, Kempe DS, Hermle T, Attanasio P, Akel A, Schafer R, Friedrich B, Risler T, Baur M, Olbricht CJ, Zimmerhackl LB, Zipfel PF, Wieder T, Lang F: Suicidal death of erythrocytes in recurrent hemolytic uremic syndrome. J Mol Med (Berl) 2006;84:378-388.

83 Nicolay JP, Schneider J, Niemoeller OM, Artunc F, Portero-Otin M, Haik G, Jr., Thornalley PJ, Schleicher E, Wieder T, Lang F: Stimulation of suicidal erythrocyte death by methylglyoxal. Cell Physiol Biochem 2006;18:223-232.

84 Lang E, Gatidis S, Freise NF, Bock H, Kubitz R, Lauermann C, Orth HM, Klindt C, Schuier M, Keitel V, Reich M, Liu G, Schmidt S, Xu HC, Qadri SM, Herebian D, Pandyra AA, Mayatepek E, Gulbins E, Lang F, Haussinger D, Lang KS, Foller M, Lang PA: Conjugated bilirubin triggers anemia by inducing erythrocyte death. Hepatology 2015;61:275-284.

85 Kempe DS, Akel A, Lang PA, Hermle T, Biswas R, Muresanu J, Friedrich B, Dreischer P, Wolz C, Schumacher U, Peschel A, Gotz F, Doring G, Wieder T, Gulbins E, Lang F: Suicidal erythrocyte death in sepsis. J Mol Med (Berl) 2007;85:273-281.

86 Lang PA, Schenck M, Nicolay JP, Becker JU, Kempe DS, Lupescu A, Koka S, Eisele K, Klarl BA, Rubben H, Schmid KW, Mann K, Hildenbrand S, Hefter H, Huber SM, Wieder T, Erhardt A, Haussinger D, Gulbins E, Lang F: Liver cell death and anemia in Wilson disease involve acid sphingomyelinase and ceramide. Nat Med 2007;13:164-170.

87 Harrison HE, Bunting H, Ordway NK, Albrink WS: The Pathogenesis of the Renal Injury Produced in the Dog by Hemoglobin or Methemoglobin. J Exp Med 1947;86:339-356.

88 Andrews DA, Low PS: Role of red blood cells in thrombosis. Curr Opin Hematol 1999;6:76-82.

89 Closse C, Dachary-Prigent J, Boisseau MR: Phosphatidylserine-related adhesion of human erythrocytes to vascular endothelium. Br J Haematol 1999;107:300-302.

90 Gallagher PG, Chang SH, Rettig MP, Neely JE, Hillery CA, Smith BD, Low PS: Altered erythrocyte endothelial adherence and membrane phospholipid asymmetry in hereditary hydrocytosis. Blood 2003;101:46254627.

91 Pandolfi A, Di Pietro N, Sirolli V, Giardinelli A, Di Silvestre S, Amoroso L, Di Tomo P, Capani F, Consoli A, Bonomini M: Mechanisms of uremic erythrocyte-induced adhesion of human monocytes to cultured endothelial cells. J Cell Physiol 2007;213:699-709.

92 Wood BL, Gibson DF, Tait JF: Increased erythrocyte phosphatidylserine exposure in sickle cell disease: flowcytometric measurement and clinical associations. Blood 1996;88:1873-1880.

93 Borst O, Abed M, Alesutan I, Towhid ST, Qadri SM, Foller M, Gawaz M, Lang F: Dynamic adhesion of eryptotic erythrocytes to endothelial cells via CXCL16/SR-PSOX. Am J Physiol Cell Physiol 2012;302:C644-C651.

94 Chung SM, Bae ON, Lim KM, Noh JY, Lee MY, Jung YS, Chung JH: Lysophosphatidic acid induces thrombogenic activity through phosphatidylserine exposure and procoagulant microvesicle generation in human erythrocytes. Arterioscler Thromb Vasc Biol 2007;27:414-421.

95 Zwaal RF, Comfurius P, Bevers EM: Surface exposure of phosphatidylserine in pathological cells. Cell Mol Life Sci 2005;62:971-988. 